\title{
The Correlation of Transaminase Enzymes on the Prognosis of Covid-19 Patients in the ICU Infection Center Dr. Wahidin Sudirohusodo General Hospital Makassar
}

\author{
Dominiques Reggy Marfilan ${ }^{1}$, Hisbullah$^{2}$, A. M. Takdir Musba ${ }^{3}$, Syamsul Hilal Salam ${ }^{4}$, \\ Faisal Muchtar ${ }^{5}$, Haizah Nurdin ${ }^{6}$ \\ 1,2,3,4,5,6 Department of Anesthesia, Intensive Care and Pain Management, Faculty of Medicine, \\ Universitas Hasanuddin/ RSUP Dr. Wahidin Sudirohusodo, Makassar, Indonesia \\ Email: dreggy88@gmail.com
}

\begin{abstract}
:
Corona Virus Disease 2019 (COVID-19) is an infectious disease that has been designated as a worldwide pandemic. Symptoms of Covid-19 are not only respiratory symptoms but also extrapulmonary symptoms, including the discovery of impaired liver function in the form of increased transaminase enzymes. Therefore, this study was conducted to see the correlation of transaminase enzymes with the prognosis of COVID-19 patients treated in the Intensive Care Unit (ICU) Dr. Wahidin Sudirohusodo Hospital. The study was conducted on June to August 2021. The cross-sectional analytical research method used retrospective medical record data for the period from July to December 2020 with a sample of 137 patients with COVID-19 confirmed. From the results of the Pearson test, patients with increased SGOT were associated with a mortality prognosis $(p=0.000, p<0.05)$ with a correlation coefficient $(r)$ of -0.383 and an increase in SGPT were associated with a mortality prognosis $(p=0.013, p<0.05)$ with a correlation coefficient ( $r$ ) of -0.211 . From the results of the Kruskal Wallis test, there were differences in prognosis in patients with increased SGOT and SGPT grades 1,2,3, and 4 ( $p=0.000$ and $p=$ 0.028). There is a correlation between the increased transaminase enzymes with the prognosis of the patient's mortality. Patients with severe elevated SGOT and SGPT enzymes had a greater prognosis of mortality than those with mild enzyme elevations. Extrapulmonary symptoms of stroke were associated with increased SGOT and myocardial infarction symptoms, and nephropathy was associated with increased SGOT and SGPT. Comorbid coronary artery disease and hepatitis were associated with increased SGOT and SGPT.
\end{abstract}

Keywords:

transaminase enzymes; SGOT; SGPT; Covid-19; prognosis

\section{Introduction}

Corona Virus Disease 2019 (COVID-19) is an infectious disease that emerged and was identified in December 2019. This disease is caused by severe acute respiratory syndrome coronavirus 2 (SARS-CoV-2) which initially appeared in Wuhan, China and then spread throughout the world. So, the World Health Organization (WHO) declared it as a pandemic. The first COVID-19 case in Indonesia was announced on March 2, 2020 or about 4 months after the first case in China. The lungs are the primary target organs for viral infections and cause the main clinical symptoms, this infection also attacks various organs including the liver and gastrointestinal tract. Overall, this viral infection can cause serious complications such as acute respiratory distress syndrome (ARDS) with multi-organ failure. This indicates that COVID-19 is considered a systemic infection and inflammatory disease. Approximately $2-10 \%$ of patients with COVID-19 who come to the hospital have gastrointestinal tract complaints such as diarrhea and abdominal pain. In addition, SARS-CoV-2 RNA was found in feces and 
the gastrointestinal tract. These findings suggest the possible presence of the virus in the liver and gastrointestinal tract (Damindro N et al, 2020; Nardo A et al, 2020, Yousaf et al, 2020).

The liver is the main organ for detoxification and metabolism, and maintaining optimal function is essential to include all available therapeutic modalities in the treatment of COVID19. Abnormal liver function requires clinical evaluation, monitoring, and specific therapy. To support clinical decision-making and optimize outcomes in the treatment of COVID-19, it is imperative to clearly understand the possible mechanisms involved in liver injury (Alqahtami SA, Schattenberg JM, 2020).

Early research from Wuhan reported an increase in liver transaminase enzymes of 20$50 \%$. However, the role of liver function and its effect on mortality remains controversial. Liver dysfunction in COVID-19 patients can arise from direct viral infection of liver cells or as a host immune system mechanism. The SARS-CoV-2 virus requires attachment to the AngiotensinConverting Enzyme 2 (ACE-2) receptor on target cells to replicate. Preliminary studies have shown that ACE-2 receptors are present in cholangiocytes, and may contribute to liver dysfunction, although post-mortem examination has not identified the presence of virus in liver tissue (Damindro N et al, 2020; Nardo A et al, 2020, Yousaf et al, 2020).

In a preliminary study conducted by Darnindro et al, patients infected with COVID-19 who were treated at Fatmawati Hospital from March-April 2020 showed that an increase in AST levels significantly correlated with high mortality rates (Damindro N et al, 2020).

This study was conducted to see the correlation of transaminase enzymes to the prognosis of COVID-19 patients treated in the Intensive Care Unit (ICU). The findings of this study can provide guidance and preparedness for ICU doctors in managing patients with COVID-19.

\section{Research Methods}

The study was carried out in June-August 2021. This study used a retrospective analytic study with a cross sectional design. Medical chart review of patients with confirmed COVID19 infection, and treated at the ICU Infection Center Dr. RSUP. Wahidin Sudirohusodo for the period July to December 2020 was done. Inclusion criteria were patients with a diagnosis of COVID-19 infection, confirmed by PCR examination, and hospitalized in the ICU Infection Center at Dr. RSUP. Wahidin Sudirohusodo, and had the results of the first transaminase enzyme examination when he entered the ICU Infection Center or when he was consulted into the ICU. Exclusion criteria were medical record data of patients with confirmed COVID-19 infection that are difficult to read or are not tested for transaminase enzymes. From 152 total patients, there were 137 samples met the criteria. Research ethics approval has been approved by the Commission on Ethics for Biomedical Research in Humans, Faculty of Medicine, Hasanuddin University.

Sample data were gender, age, intrapulmonary symptoms, extrapulmonary symptoms, comorbidities, SGOT and SGPT enzyme test results when the patient was admitted to the ICU and patient's prognosis. The normality test used the Kolmogorov-Smirnov test, then the correlation used the Pearson test. The Kruskal-Wallis test was used to assess the severity of transaminase enzymes elevation with the prognosis of COVID-19 patients. the Chi-Square test the correlation of intrapulmonary symptoms, extrapulmonary symptoms and comorbid diseases to the increase transaminases enzymes. Statistical analysis used SPSS 22.0 for windows program. 


\section{Discussion}

This study obtained 137 medical record data of patients diagnosed with confirmed COVID-19 and treated in the ICU IC, Dr. Wahidin Sudirohusodo for the period July 1, 2020 to December 31, 2020 (6 months) who met the inclusion criteria.

Table 1. Overview of Research Subject Characteristics

\begin{tabular}{|c|c|c|c|c|}
\hline No & Factor & & $\mathbf{N}$ & $\%$ \\
\hline \multirow[t]{3}{*}{1} & \multirow[t]{2}{*}{ Gender } & Man & 93 & 67.8 \\
\hline & & Woman & 44 & 32.2 \\
\hline & \multicolumn{2}{|l|}{ Total } & 137 & 100 \\
\hline \multirow[t]{6}{*}{2} & \multirow[t]{5}{*}{ Age } & $<30$ years old & 16 & 11.7 \\
\hline & & $31-45$ & 28 & 20.4 \\
\hline & & $46-55$ & 28 & 20.4 \\
\hline & & $56-65$ & 35 & 25.6 \\
\hline & & $>65$ & 30 & 21.9 \\
\hline & \multicolumn{2}{|l|}{ Total } & 137 & 100 \\
\hline \multirow[t]{5}{*}{3} & \multirow{4}{*}{$\begin{array}{l}\text { Intrapulmonary } \\
\text { Symptoms }\end{array}$} & None & 8 & 5.8 \\
\hline & & Congested & 99 & 72.2 \\
\hline & & ARDS & 26 & 19 \\
\hline & & Pleural Effusion & 4 & 3 \\
\hline & \multicolumn{2}{|l|}{ Total } & 137 & 100 \\
\hline \multirow[t]{4}{*}{4} & \multirow{4}{*}{$\begin{array}{l}\text { Extrapulmon } \\
\text { ary Symptoms }\end{array}$} & None & 101 & 73.7 \\
\hline & & $\begin{array}{l}\text { Myocardial } \\
\text { Infarction }\end{array}$ & 8 & 5.8 \\
\hline & & Sepsis & 6 & 4.4 \\
\hline & & $\begin{array}{l}\text { Loss of } \\
\text { consciousness }\end{array}$ & 6 & 4.4 \\
\hline
\end{tabular}




\begin{tabular}{|c|c|c|c|c|}
\hline & & Nephropathy & 5 & 3.6 \\
\hline & & DIC & 4 & 2.9 \\
\hline & & stroke & 3 & 2.2 \\
\hline & & $\begin{array}{l}\text { Gastrointestinal } \\
\text { Complaints }\end{array}$ & 3 & 2.2 \\
\hline & & Seizure & 1 & 0.8 \\
\hline & Total & & 137 & 100 \\
\hline 5 & Comorbid & None & 46 & 33.6 \\
\hline & & $\mathrm{DM}$ & 37 & 27 \\
\hline & & Hypertension & 27 & 19.7 \\
\hline & & CKD & 10 & 7.3 \\
\hline & & CAD & 8 & 5.9 \\
\hline & & Hepatitis & 5 & 3.6 \\
\hline & & COPD & 2 & 1.5 \\
\hline & & Obesity & 1 & 0.7 \\
\hline & & HIV & 1 & 0.7 \\
\hline & Total & & 137 & 100 \\
\hline 6 & Prognosis & Not Survive & 57 & 41.6 \\
\hline & & Surivive & 80 & 58.4 \\
\hline & Total & & 137 & 100 \\
\hline
\end{tabular}

From table 1, the majority of COVID-19 patients in the ICU were 56-65 years old, with the age range from 18 to 80 years old. There were $94.2 \%$ who experienced intrapulmonary symptoms and $26.3 \%$ who experienced extrapulmonary symptoms, and $66.4 \%$ who had comorbidities. Prognosis was $41.6 \%$ patients not survived.

Table 2. The Correlation of SGOT Enzyme Elevation on Prognosis

SGO

T Prognosis 


\begin{tabular}{llr|r}
\hline \multirow{2}{*}{$\begin{array}{l}\text { SGO } \\
\mathrm{T}\end{array}$} & Pearson & 1 &,$- 383^{* *}$ \\
& Correlation & & \\
\cline { 2 - 4 } & Sig. (2-tailed) & &, 000 \\
\cline { 2 - 4 } & $\mathrm{N}$ & 137 & 137 \\
\hline \multirow{2}{*}{ osis } & Pearson & - & 1 \\
& Correlation &, $383^{*}$ & \\
\cline { 2 - 4 } & & $*$ & \\
& Sig. (2-tailed) &, $000 \mathrm{~b}$ & \\
\cline { 2 - 4 } & $\mathrm{N}$ & 137 & 137 \\
\hline
\end{tabular}

Pearson Correlation test. Significant if $\mathrm{p}$ value $<0.05$

Based on table 2, it was found that there was a correlation between elevation of SGOT enzyme and the patient's prognosis $(\mathrm{p}=0.000, \mathrm{p}<0.05)$ with coefficient correlation $(\mathrm{r})$ of -0.383 . The coefficient correlation is negative, which means that the higher SGOT enzyme elevation, the smaller the patient's prognosis.

Table 3. The Correlation of SGPT Enzyme Elevation on Prognosis

\begin{tabular}{|c|c|c|c|}
\hline & & SGPT & Prognosis \\
\hline \multirow[t]{4}{*}{ SGPT } & Pearson & 1 &,$- 211 *$ \\
\hline & Correlation & & \\
\hline & Sig. (2-tailed) & & 0.013 \\
\hline & $\mathrm{N}$ & 137 & 137 \\
\hline \multirow[t]{4}{*}{ Prognosis } & Pearson &,$- 211 *$ & 1 \\
\hline & Correlation & & \\
\hline & Sig. (2-tailed) &, $013 b$ & \\
\hline & $\mathrm{N}$ & 137 & 137 \\
\hline
\end{tabular}

Based on table 3, it was found that there was a correlation between elevation of SGPT enzyme on the patient's prognosis $(\mathrm{p}=0.013, \mathrm{p}<0.05)$ with coefficient correlation $(\mathrm{r})$ of -0.211 . The correlation coefficient is negative, which means the higher SGPT enzyme elevation, the smaller the patient's prognosis. 
Table 4. The Relationship between the degree of SGOT Enzyme elevation and Prognosis

\begin{tabular}{|c|c|c|c|c|c|c|}
\hline \multicolumn{3}{|c|}{ Liver Enzyme } & \multicolumn{3}{|c|}{ Prognosis } & \multirow{3}{*}{$\begin{array}{l}\text { p value } \\
0.000\end{array}$} \\
\hline & & & \multirow{2}{*}{$\begin{array}{l}\text { Not Survived } \\
16\end{array}$} & \multirow{2}{*}{\begin{tabular}{|l} 
Survived \\
49
\end{tabular}} & \multirow{2}{*}{$\begin{array}{l}\text { Total } \\
65\end{array}$} & \\
\hline \multirow[t]{10}{*}{ SGOT } & \multirow[t]{2}{*}{ Normal } & Amount & & & & \\
\hline & & Percent & $24.6 \%$ & $75.4 \%$ & $100 \%$ & \\
\hline & \multirow[t]{2}{*}{ Grade 1} & Amount & 26 & 26 & 52 & \\
\hline & & Percent & $50 \%$ & $50 \%$ & $100 \%$ & \\
\hline & \multirow[t]{2}{*}{ Grade 2} & Amount & 9 & 5 & 14 & \\
\hline & & Percent & $64.3 \%$ & $35.7 \%$ & $100 \%$ & \\
\hline & \multirow[t]{2}{*}{ Grade 3} & Amount & 5 & 0 & 5 & \\
\hline & & Percent & $100 \%$ & $0 \%$ & $100 \%$ & \\
\hline & \multirow[t]{2}{*}{ Grade 4} & Amount & 1 & 0 & 1 & \\
\hline & & Percent & $100 \%$ & 0 & $100 \%$ & \\
\hline \multirow[t]{10}{*}{ SGPT } & \multirow[t]{2}{*}{ Normal } & Amount & 25 & 49 & 74 & 0.028 \\
\hline & & Percent & $33.8 \%$ & $66.2 \%$ & $100 \%$ & \\
\hline & \multirow[t]{2}{*}{ Grade 1} & Amount & 21 & 24 & 45 & \\
\hline & & Percent & $46.7 \%$ & $53.3 \%$ & $100 \%$ & \\
\hline & \multirow[t]{2}{*}{ Grade 2} & Amount & 9 & 7 & 16 & \\
\hline & & Percent & $56.3 \%$ & $43.8 \%$ & $100 \%$ & \\
\hline & \multirow[t]{2}{*}{ Grade 3} & Amount & 1 & 0 & 1 & \\
\hline & & Percent & $100 \%$ & $0 \%$ & $100 \%$ & \\
\hline & \multirow[t]{2}{*}{ Grade 4} & Amount & 1 & 0 & 1 & \\
\hline & & Percent & $100 \%$ & $0 \%$ & $100 \%$ & \\
\hline
\end{tabular}

Kruskal-Wallis test. Significant if p value $<0.05$

Based on table 4, it was found that there was a difference between elevation of SGOT enzymes grades 1,2,3 and 4 on the prognosis of patients with $p=0.00(p<0.05)$, which means the higher the level of SGOT enzyme elevation, the worse the patient's prognosis. Then it was also found that there were a difference between elevation of SGPT enzyme grades 1,2,3 and 4 on the prognosis of patients with $\mathrm{p}=0.028(\mathrm{p}<0.05)$, which means the higher the level of the increase in the SGOT enzyme, the worse patient prognosis. Thus, it can be concluded that there is a significant difference between degrees 1,2,3 and 4 of the increase in the Transaminase enzyme to the worsening of the prognosis in COVID-19 patients treated at the ICU IC, Dr. Wahidin Sudirohusodo, where the higher the level of increase in the patient's Transaminase enzyme, the worse the patient's prognosis.

Table 5. Risk of Increased SGOT and SGPT with Prognosis

\begin{tabular}{|l|l|l|l|}
\hline Liver Enzyme & $\begin{array}{l}\text { Coefficient of } \\
\text { Determination }\end{array}$ & $\begin{array}{l}\text { Odds } \\
\text { Ratio }\end{array}$ & $\begin{array}{l}\mathbf{p} \\
\text { value }\end{array}$ \\
\hline SGOT & 14.4 & 3.45 & 0.000 \\
\hline SGPT & 4.44 & 0.568 & 0.017 \\
\hline
\end{tabular}

Odds Ratio, Significant if the value of $\mathrm{p}<0.05$ 
Based on table 5, The correlation of the SGOT elevation with not survived prognosis were $14.4 \%$. Where COVID patients treated in the ICU with an increase in SGOT were 3.45 times more likely to die compared to patients who did not experience an increase in SGOT. In this study, the correlation of SGPT elevation with not survived prognosis were $4.44 \%$. Where COVID patients who are treated in the ICU with an increase in SGPT are 0.568 times more likely to die compared to patients who do not experience an increase in SGPT. In this study found a value of $\mathrm{p}<0.05$, which means this Odd Ratio can be applied to the general population.

Table 6. Correlation between Intrapulmonary Symptoms, Extrapulmonary Symptoms, and Comorbidities to Elevated Transaminase Enzymes

\begin{tabular}{|c|c|c|c|c|c|c|c|}
\hline \multirow[t]{2}{*}{ Variable } & & \multicolumn{2}{|c|}{ SGOT } & \multirow[t]{2}{*}{$p$ value } & \multicolumn{2}{|c|}{ SGPT } & \multirow[t]{2}{*}{ p value } \\
\hline & & Normal & Increase & & Normal & Increase & \\
\hline \multicolumn{8}{|c|}{ Intrapulmonary Symptoms } \\
\hline \multirow[t]{2}{*}{ Congested } & No & 19 & 19 & \multirow[t]{2}{*}{0.108} & 18 & 20 & \multirow[t]{2}{*}{0.438} \\
\hline & Yes & 46 & 53 & & 56 & 43 & \\
\hline \multirow[t]{2}{*}{ ARDS } & No & 53 & 58 & \multirow[t]{2}{*}{0.989} & 60 & 51 & \multirow[t]{2}{*}{0.974} \\
\hline & Yes & 12 & 14 & & 14 & 12 & \\
\hline \multirow[t]{2}{*}{ Pleural Effusion } & No & 63 & 70 & \multirow[t]{2}{*}{0.943} & 72 & 61 & \multirow[t]{2}{*}{0.921} \\
\hline & Yes & 2 & 2 & & 2 & 2 & \\
\hline \multicolumn{8}{|c|}{ Extrapulmonary Symptoms } \\
\hline \multirow[t]{2}{*}{ Sepsis } & No & 61 & 70 & \multirow[t]{2}{*}{0.778} & 70 & 61 & \multirow[t]{2}{*}{0.908} \\
\hline & Yes & 4 & 2 & & 4 & 2 & \\
\hline \multirow[t]{2}{*}{ Loss of consciousness } & No & 62 & 69 & \multirow[t]{2}{*}{0.884} & 69 & 62 & \multirow[t]{2}{*}{0.677} \\
\hline & Yes & 3 & 3 & & 5 & 1 & \\
\hline \multirow[t]{2}{*}{ stroke } & No & 64 & 70 & \multirow[t]{2}{*}{0.000} & 73 & 61 & \multirow[t]{2}{*}{0.055} \\
\hline & Yes & 1 & 2 & & 1 & 2 & \\
\hline \multirow[t]{2}{*}{ Seizure } & No & 65 & 71 & \multirow[t]{2}{*}{0.800} & 74 & 62 & \multirow[t]{2}{*}{0.725} \\
\hline & Yes & 0 & 1 & & 0 & 1 & \\
\hline \multirow[t]{2}{*}{ Myocardial Infarction } & No & 63 & 66 & \multirow[t]{2}{*}{0.000} & 72 & 57 & \multirow[t]{2}{*}{0.001} \\
\hline & Yes & 2 & 6 & & 2 & 6 & \\
\hline \multirow[t]{2}{*}{ DIC } & No & 63 & 70 & \multirow[t]{2}{*}{0.943} & 72 & 61 & \multirow[t]{2}{*}{0.942} \\
\hline & Yes & 2 & 2 & & 2 & 2 & \\
\hline
\end{tabular}




\begin{tabular}{|c|c|c|c|c|c|c|c|}
\hline \multicolumn{2}{|l|}{ Variable } & \multicolumn{2}{|c|}{ SGOT } & \multirow{4}{*}{\begin{tabular}{r|} 
p value \\
0.494
\end{tabular}} & \multicolumn{2}{|c|}{ SGPT } & \multirow{4}{*}{$\begin{array}{r}\text { p value } \\
0.974\end{array}$} \\
\hline & & \multirow{2}{*}{ 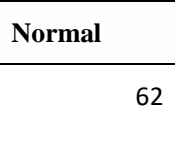 } & Increase & & Normal & Increase & \\
\hline Gastro & No & & 62 & & 72 & 62 & \\
\hline & Yes & 3 & 0 & & 2 & 1 & \\
\hline \multirow[t]{2}{*}{ Nephropathy } & No & 63 & 69 & \multirow[t]{2}{*}{0.000} & 71 & 61 & \multirow[t]{2}{*}{0.000} \\
\hline & Yes & 2 & 3 & & 3 & 2 & \\
\hline \multicolumn{8}{|l|}{ Comorbid } \\
\hline \multirow[t]{2}{*}{ DM } & No & 47 & 53 & \multirow[t]{2}{*}{0.587} & 54 & 46 & \multirow[t]{2}{*}{0.795} \\
\hline & Yes & 18 & 19 & & 20 & 17 & \\
\hline \multirow[t]{2}{*}{ Hypertension } & No & 54 & 56 & \multirow[t]{2}{*}{0.344} & 59 & 51 & \multirow[t]{2}{*}{0.145} \\
\hline & Yes & 11 & 16 & & 15 & 12 & \\
\hline \multirow[t]{2}{*}{ CAD } & No & 61 & 68 & \multirow[t]{2}{*}{0.000} & 70 & 59 & \multirow[t]{2}{*}{0.009} \\
\hline & Yes & 4 & 4 & & 4 & 4 & \\
\hline \multirow[t]{2}{*}{ COPD } & No & 65 & 70 & \multirow[t]{2}{*}{0.506} & 73 & 62 & \multirow[t]{2}{*}{0.978} \\
\hline & Yes & 0 & 2 & & 1 & 1 & \\
\hline \multirow[t]{2}{*}{ CKD } & No & 60 & 67 & \multirow[t]{2}{*}{0.795} & 68 & 59 & \multirow[t]{2}{*}{0.991} \\
\hline & Yes & 5 & 5 & & 6 & 4 & \\
\hline \multirow[t]{2}{*}{ Obesity } & No & 65 & 71 & \multirow[t]{2}{*}{0.800} & 73 & 63 & \multirow[t]{2}{*}{0.931} \\
\hline & Yes & 0 & 1 & & 1 & 1 & \\
\hline \multirow[t]{2}{*}{ Hepatitis } & No & 64 & 68 & \multirow[t]{2}{*}{0.007} & 74 & 58 & \multirow[t]{2}{*}{0.031} \\
\hline & Yes & 1 & 4 & & 0 & 5 & \\
\hline HIV & No & 65 & 71 & 0.800 & 74 & 62 & 0.725 \\
\hline & Yes & 0 & 1 & & 0 & 1 & \\
\hline
\end{tabular}

Chi-Square Test. Significant if $\mathrm{p}$ value $<0.05$

Based on table 6 , it was found that there was no correlation between intrapulmonary symptoms and the increase in SGOT and SGPT enzymes $(\mathrm{p}>0.05)$. There was a correlation between extrapulmonary symptoms of stroke and an increase in the SGOT enzyme, while 
Myocardial Infarction and Nephropathy were correlated with an increase in the SGOT and SGPT enzymes $(\mathrm{p}<0.05)$. There is a correlation between comorbid CAD and hepatitis with an increase in SGOT and SGPT.

\section{Discussion}

This study assessed the correlation of transaminase enzymes to the prognosis of COVID-19 patients treated at the ICU Infection Center Dr. Wahidin Sudirohusodo from 1 July 2020 to 31 December 2020 (6 months). The 137 COVID-19 patients treated at the ICU Infection Center RSUP. Dr. Wahidin Sudirohusodo, 57 patients (41.6\%) died. This is in accordance with Darnindro's study at RS. Fatmawati where a mortality of $45.5 \%$ was found. However, this mortality rate exceeds the national mortality rate of $6.3 \%$. This could be caused that the patients who included in this study had COVID-19 infection with severe symptoms.

Mortality in COVID-19 patients is correlated with various factors, one of which is liver dysfunction. Impaired liver function in COVID-19 patients has been reported by Chen et al (2020) in 99 patients in Wuhan. This study reported an increase in SGOT, SGPT and lactate dehydrogenase (LDH) in $43.4 \%$ of patients. However, this finding was different in the study of Yang et al (2020), which found only $29 \%$ had abnormal liver function, and no difference was found between abnormal liver function survivors (30\%) and non-survivors $(28 \%)$.

In COVID-19 patients being treated in the ICU, Dr. Wahidin Sudirohusodo found that there were 72 patients $(52.55 \%)$ who experienced an increase in the SGOT enzyme, where most widely in grade 1 (SGOT elevation between 1.25-2.4x from the upper limit of the normal value) as many as 52 patients (37.96\%). An increase in SGPT enzyme was found in 67 patients (48.91\%) where most widely in grade $1(1.25-2.4 \mathrm{x}$ of the upper limit of normal value) as many as 45 patients $(32.85 \%)$.

These results were found to be similar to the findings of Fan $\mathrm{Z}$ et al (2020) conducting a retrospective study on 148 COVID-19 patients in Shanghai, China. Abnormal liver function was found as many as $55(37.2 \%)$. Patients with abnormal liver function had a longer treatment time $(15.09+4.79$ days $)$ than patients with normal liver function $(12.76+4.14$ days $)$.

Phipps et al studied a retrospective multicenter cohort study of 2273 COVID-19 patients in the USA, with a mean patient age of 65 years. Liver damage was categorized as mild ( $<2$ times the upper limit of normal value), moderate (2-5 times the upper limit of normal value), and severe ( $>5$ times the upper limit of normal value). Five percent had chronic liver disease. All of COVID-19 patients who participated in the study, 45\% had mild liver damage, $21 \%$ moderate liver damage, and 6.4\% severe liver damage. Moderate and severe liver damage was more common in patients requiring ICU care. Multivariate analysis showed severe acute hepatic impairment was correlated with increased inflammatory markers including ferritin, and interleukin 6 (IL-6). It appears that $23 \%$ of patients require ICU level care, among patients with severe hepatic impairment ( $n=145), 69 \%$ required ICU care. These results also support this study where the increase in enzymes grades 1 (1.25-2.4x from the upper limit of the normal value) and grade 2 (2.5-5x the upper limit of the normal value) was found more than degrees 3 and 4 (above $5 x$ the upper limit). normal value).

From the results of the Pearson test in this study, it was found that there was a correlation between the increase in the SGOT enzyme on the patient's ad vitam prognosis ( $\mathrm{p}=$ $0.000)$ and there was a correlation between the increase in the SGPT enzyme on the patient's ad vitam prognosis $8 x(p=0.013)$. The elevation of the transaminase enzyme correlates with 
the death of COVID-19 patients treated at the ICU Infection Center Dr. Wahidin Sudirohusodo.

In this study, it was also found that there was a correlation between the degree of the SGOT and SGPT Transaminase enzymes elevation to the worsening of the prognosis in COVID-19 patients who were treated at the ICU Infection Center Dr. Wahidin Sudirohusodo $(p=0.00$ and $p=0.028, p<0.05)$. This is in accordance with the research of Darnindro et al, where abnormal SGOT levels increased more than twice the threshold value had a higher proportion of mortality compared to SGOT levels with an increase of only 1-2 times the threshold value $(>34 \mathrm{~g} / \mathrm{dl})$, and an increase in SGOT 1-2 times of the threshold value has a higher proportion of mortality than normal SGOT. However, the increase in SGPT on mortality was different from Darnindro's study which stated that there was no correlation between the increase in SGPT and mortality $(\mathrm{p}=0.479)$. This can be caused because in this study the subjects were obtained from the Intensive Care Unit where COVID-19 infection with severe symptoms, while in Darnindro's study, the research subjects were taken from all COVID-19 patients in the ward room. This difference in findings was explained in the study of Huang et al, where patients with severe symptoms had an increased incidence of abnormal liver function compared to patients with mild-moderate symptoms. Elevated SGOT levels were found in $8(62 \%)$ of the 13 patients in the ICU compared to 7 patients $(25 \%)$ in the 25 patients who did not require ICU care.

In this study, it was found that the correlation of an increase in SGOT to Covid patients died by 14.4\%, where COVID-19 patients treated in the ICU with an increase in SGOT were 3.45 times more likely to die compared to patients who did not experience an increase in SGOT. In this study, it was found that the correlation of an increase in SGPT to Covid patients died by $4.44 \%$. Where COVID-19 patients who are treated in the ICU with an increase in SGPT are 0.568 times more likely to die compared to patients who do not experience an increase in SGPT. This is in accordance with the findings of Darnindro et al in RS. Fatmawati who showed that SGOT elevation correlated with a higher risk of mortality, with risk ratio of 3.4 for SGOT elevation and a risk ratio of 1.48 for SGPT elevation. These results are in accordance with the research of Arifputra et al in Manado, Indonesia. They found that out of a total of 126 patients with COVID-19, there were $57(45.2 \%)$ patients who had abnormal liver tests. There was a significant difference in the mean SGOT and NLR between non-surviving and surviving COVID-19 patients. High SGOT ( $\geq 34.5 \mathrm{U} / \mathrm{L})$ and NLR ( $\geq 4.7)$ were independently associated with the outcome of non-survival COVID-19 patients with odds ratios of 5.31 and 9.49, the results showed that an increase in SGPT and NLR at the time of hospitalization for COVID19 patients is correlated with a high risk of mortality. Therefore, SGPT and NLR can be significant prognostic in COVID-19 patients (Arifputra et al, 2021). According to Medetalibeyoglu et al, Based on Medetalibeyoglu et al, it was found that the mortality rate and the need for ICU care were statistically significant in COVID-19 patients with increased levels of SGPT and SGOT when the patient was initially treated at the RSUP (Medetalibeyoglu, et al, 2020).

According to Saini et al, there was an increase in liver enzymes in 89 patients $(58.5 \%)$ out of a total of 170 COVID-19 patients treated at PGIMER (Post Graduate Institute of Medical Education and Research) India. Deterioration requiring ICU care was found in 43 of the 89 patients who had elevated transaminase enzymes. This enzymes elevation correlated with an elevation of inflammatory markers such as CRP and ferritin.

In this study, there were no correlation between intrapulmonary symptoms and SGOT and SGPT enzymes elevation. The management of intrapulmonary symptoms of patients treated at the ICU Infection Center Wahidin Hospital was maintained well so as not to induce 
hypoxic hepatitis yet. However, this requires further research between oxygen saturation levels during treatment and an increase in liver enzymes.

However, a correlation was found between extrapulmonary symptoms, such as Stroke $(p=0.00)$, Myocardial Infarction $(p=0.00)$, and Nephropathy $(p=0.00)$ with the SGOT enzyme elevation. Other extrapulmonary symptoms, such as sepsis, loss of consciousness, seizures, DIC, and gastrointestinal complaints were not correlated with elevated SGOT enzymes ( $>>0.05)$. This is in accordance with Kim et al study, that SGOT is found in the cytosol and mitochondria, widely distributed throughout the body and is found in organs sequentially from highest to lowest in the liver, heart muscle, skeletal muscle, kidney, brain, pancreas, lungs, leukocytes, and erythrocytes. The extrapulmonary symptoms of COVID-19 infection in the form of stroke, myocardial infarction and nephropathy can cause an increase in the SGOT enzyme.

There was a correlation between extrapulmonary symptoms, such as Myocardial Infarction $(p=0.001)$, and Nephropathy $(p=0.00)$ with the SGPT enzymes elevation. However, other extrapulmonary symptoms, such as sepsis, loss of consciousness, stroke, seizures, DIC, gastrointestinal complaints were not correlated with elevated SGPT enzymes ( $p>0.05)$. This is in accordance with the theory that the SGPT enzyme is the main enzyme found in liver cells and is effective in diagnosing hepatocellular destruction. This enzyme is also found in small amounts in heart muscle, kidney, and skeletal muscle. The extrapulmonary symptoms of COVID-19 patients in the ICU in the form of myocardial infarction and nephropathy correlate with an increase in the SGPT enzyme.

From this study it can also be seen that the most extrapulmonary symptoms are myocardial infarction by $8 \%$. This showed that extrapulmonary symptoms of COVID-19 sufferers can be in the form of cardiovascular disease. (Zheng Y, et al. 2020). Data from China's National Health Commission shows that 35\% of patients diagnosed with COVID-19 have hypertension and $17 \%$ have coronary heart disease. A recent meta-analysis of 8 studies from China including 46,248 infected patients showed that the most common comorbidity was hypertension. (17\% $\pm 7 \%$ [95\% CI, $14 \%$ to $22 \%]$ ) and DM (8\% $\pm 6 \%[95 \% \mathrm{CI}, 6 \%$ to $11 \%]$ ), followed by CVD $(5 \% \pm 4 \%$ [95 \%CI, 4\% to 7\%]).23 The mechanism of this correlation remains unclear. (Zang J, et al. 2020).

In this study, it was found that there were 91 patients (66.4\%) out of 137 patients who had comorbid, of which 5 patients $(3.6 \%)$ had comorbid hepatitis. It was found that there was a correlation between comorbid factors of CAD and hepatitis with an increase in SGOT and SGPT enzymes $(\mathrm{p}<0.05)$. Meanwhile, other comorbid factors, such as Diabetes Mellitus, Hypertension, COPD, CKD, Obesity, and HIV did not correlate with an increase in the SGOT and SGPT enzymes ( $p>0.05)$. This is in accordance with the study of Kulkani AV, et al in a large-scale meta-analysis which showed that the prevalence of COVID-19 with chronic liver disease and patients in critical condition was 3.6\% and 3.9\%, respectively, where the disease worsened and the prognosis was poor, respectively. In Zou X et al's study with 105 COVID-19 patients with chronic hepatitis B virus coinfection, the increase in liver enzymes in these patients was relatively common at the beginning of treatment and significantly increased during treatment, where 14 patients $(13.33 \%)$ showed impaired liver function. liver, and was more common in men $(\mathrm{p}=0.001)$. Patients with liver damage have a higher proportion of severe cases, complications, and mortality.

This study shows that the increase in the transaminase's enzyme in COVID-19 patients treated at the ICU Infection Center is generally mild, which the enzyme elevation levels up to 5 
times the upper limit of normal. The degree of enzyme elevation showed a poor prognosis as well. Several theories have been proposed to explain the mechanism of liver damage in COVID19 infection. The SARS-CoV2 virus has been shown to use the angiotensin 2-converting enzyme (ACE-2) as a site of cell entry. In healthy liver tissue, ACE 2 is most abundant in cholangiocytes. The process of direct viral entry into these cells could be the cause of the increase in the transaminase's enzyme found in COVID-19 patients. Several other causes such as medication and nutrition, hypoxia levels, or other causes such as the use of potentially hepatotoxic drugs such as remdesir, acetaminophen or corticosteroids that can interfere with liver function and increase transaminases enzymes can be the subject of further research in COVID-19 patients. In this study, intrapulmonary symptoms such as shortness of breath and pleural effusion have not been shown to correlate with elevated transaminase enzymes.

In the Lei $\mathrm{P}$ et al study, a retrospective cohort of 115 patients found significant differences in SGPT, albumin and CRP levels in the severe group of patients. Some findings on CT scan of the upper abdomen showed hepatic hypodensity $(26.09 \%)$ which is often found in critically ill patients $(58.82 \%)$, and perycholescystic fat stranding $(21.27 \%)$. This suggests that COVID-19 infection can cause multiple organ dysfunction syndrome (MODS) including liver damage. Pathological examination of the liver revealed moderate steatosis and mild lobular and portal activity in a COVID-19 patient. Hepatic hypodensity is a common sign of hepatic steatosis or acute hepatitis, while other imaging signs of acute hepatitis include hepatomegaly, periportal edema, gallbladder wall edema, periportal lymphadenopathy were not found in the patients in this study.

In the retrospective study of Liao FL et al, in 147 patients with COVID-19, 56 (38.1\%) patients had abnormal SGPT and $80(54.4 \%)$ patients had abnormal SGOT. The peak of abnormality was on days 3-6 of treatment and correlated with acute liver damage induced by SARS-CoV 2. Diammonium Glycyrrhizinate (DG) therapy can relieve abnormal activity of liver enzymes in non-critical COVID-19 patients. This therapy needs to be further investigated for therapy in critically ill COVID-19 patients treated in the ICU to treat elevated liver enzymes. It is also necessary to pay attention to the presence of underlying or previously undiagnosed liver disease in COVID-19 patients, and to consider comorbidities that have a high risk of improving liver function and correlate the patient's prognosis. Also, the possibility of hidden fatty liver disease. It is necessary to consider abdominal CT scans in COVID-19 patients with severe liver enzyme elevations and early therapeutic intervention to treat them in order to prevent further elevation of liver enzymes and prevent worsening of COVID-19 patients admitted to the ICU.

\section{Conclusion}

There is a correlation between the increase in Transaminase Enzymes (SGOT and SGPT) on the prognosis of COVID-19 patients treated at the ICU Infection Center Dr. Wahidin Sudirohusodo, where the higher the degree of increase in the Transaminase Enzyme, the worse the patient's prognosis. Intrapulmonary symptoms do not correlate with elevated transaminase enzymes (SGOT and SGPT). It was found that there was a correlation between extrapulmonary symptoms such as Stroke, Myocardial Infarction, and Nephropathy to an increase in the SGOT enzyme, and there was a correlation between extrapulmonary symptoms such as Myocardial Infarction, and Nephropathy to an increase in the SGPT enzyme. There is a correlation of comorbid coronary artery disease and hepatitis to the increase in transaminase enzymes (SGOT and SGPT) in COVID-19 patients treated at the ICU Infection Center RSUP. Dr. Wahidin Sudirohusodo. 


\section{References}

Aleya dan Berawi, K. N. 2015. Korelasi Pemeriksaan Laboratorium SGOT/SGPT dengan Kadar Bilirubin pada Pasien Hepatitis C di Ruang Penyakit Dalam RSUD Dr. H. Abdul Moeloek Provinsi Lampung pada Bulan Januari - Desember 2014. Available at: http://repository.lppm.unila.ac.id/1389/1/25.pdf. Diakses pada tanggal 22 januari 2021.

Alqahtani SA, Schattenberg JM. Liver injury in COVID-19: The current evidence. United European Gastroenterology Journal 2020, Vol. 8(5) 509-519

Alsalhen KS, Abdalsalam RD, 2013. Effect of Cigarette Smoking on Liver Functions. International Current Pharmaceutical Journal. http://www.iciponline.com/docments/Vol3Issue7/01.pdf.

Arifputra J, Waleleng BJ, Gosal Fandy, Wenas NT, Rotty L, Winarta J, dkk. Liver transaminase levels and neutrofil to lymphocyte ratio as prognostic and predictor in Coronavirus Disease 2019. Macedonian Journal of Medical Sciences. 2020 Oct 26; 8(T1):282-285.

Boregowda U, Aloysius MM, Perisetti A, Gajendran M, Bansal P, Goyal H. Serum Activity of Liver Enzymes Is Associated with Higher Mortality in COVID-19: A Systemic Review and Meta-Analysis. Frontiers in Medicine July 2020, Vol 7. Article 431. www.frontiersin.org

Cai Q, Huang D, Yu H, Zhu Z, Xia Z, Su Y, et al. COVID-19: Abnormal liver finction tests. J. Hepatol 2020; 73:566-74.

Conreng, D., Waleleng, B. J. dan Palar, S. 2014. Korelasi Konsumsi Alkohol dengan Gangguan Fungsi Hati pada Subjek Pria Dewasa Muda di Kelurahan Tateli dan Teling Atas Manado. Available

at: https://ejournal.unsrat.ac.id/index.php/eclinic/article/download/5026/4544. Diakses pada tanggal 5 januari 2021.

Chen N, Zhou M, Dong X, Qu J, Gong F, Han Y, et al. Epidemiological and clinical characteristics of 99 cases of 2019 novel coronavirus pneumonia in Wuhan, China: a descriptive study. Lancet 2020; 395:507-13.

Darnindro N, Mokoagow MI, Manurung A, Nasarudin J, Wardoyo EY, Sari AP, Djojo AY, Iskandar M, Mardiyah R, Aji G, Magfira N, Epriliawati M, Mulyana E, Harahap A. Association of Aspartate Aminotransferase (AST) and Alanine Aminotransferase (ALT) with Mortality in Patients with Coronavirus Disease 2019 (COVID-19) in Fatmawati General Hospital: A Preliminary Data. Vol.21, Number 2, August 2020.

Depkes RI. 2007. Pharmaceutical Care untuk Penyakit Hati. Direktorat Bina Farmasi Komunitas dan Klinik. Ditjen Bina Kefarmasian dan Alat Kesehatan

Ghoda A, Ghoda M. Liver Injury in COVID-19 Infection: A Systematic Review.10 (July 31, 2020) Cureus 12(7): e9487. DOI 10.7759/cureus.9487

Habib S, Obaid SS. Approach to Jaundice and Liver Function Test Results. Zakim and Boyes's Hepatology A textbook of Liver Disease. 7th edition. 2018. Elsevier: Philadelphia.

Hikmah, E. N. 2014. Penggunaan Obat-Obatan Penginduksi Penyakit Hati terhadap Pasien Gangguan Fungsi Hati di RSUP X Surakarta Tahun 2013. Available at: http://eprints.ums.ac.id/31187/10/NASKAH_PUBLIKASI.pdf. Diakses pada tanggal 22 januari 2021.

Huang C, Wang Y, Li X, et al. Clinical features of patients infected with 2019 novel coronavirus in Wuhan, China. Lancet 2020; 395: 497-506.

Hunt RH, East JE, Lanas A, Malfertheiner P, Satsangi J, Scarpignato C, et.al. COVID-19 and Gastrointestinal Diseas Implications for the Gastroenterologist. Review Article. Dig Dis DOI: 10.1159/000512152. Published online: October 9, 2020.

Jang, E. S., Jeong, S.-H., Hwang, S. H., Kim, H. Y., Ahn, S. Y., Lee, J., Lee, S. H., Park, Y. S., Hwang, J. H., Kim, J.-W., Kim, N. dan Lee, D. H. 2012. Effects of coffee, smoking, and 
alcohol on liver function tests: a comprehensive cross-sectional study. Available at: https://www.ncbi.nlm.nih.gov/pmc/articles/PMC3531257/pdf/1471-230X-12-

145.pdf. Diakses pada tanggal 12 Februari 2018.

Jothimani D, Venugopal R, Abedin MF, Kaliamoorthy I, Rela M. COVID-19 and the liver. Journal of Hepatology 2020 vol.73. 1231-40

Kee, J. L. 2008. Pedoman Pemeriksaan Laboratorium \& Diagnostik. 6th edn. Edited by R. P. Kapoh. Jakarta: Buku Kedokteran EGC.

Kim, W. R., Flamm, S. L., Bisceglie, A. M. Di dan Bodenheimer, H. C. 2008. Serum Activity of Alanine Aminotransferase (ALT) as an Indicator of Health and Disease. Available at: https://s3.amazonaws.com/objects.readcube.com. Diakses pada tanggal 12 Februari 2018.

Kumar P, Kulkami A, Sharma M, Padaki NR. Pathogenesis of Liver Injury in COVID-19. Journal of Clinical and Experimental Hepatology. 2020. https://www.researchgate.net/publication/341518308

Lagana SM, Kudose S, Iuga AC, Lee MJ, Fazlollahi L, Remotti H. Hepatic pathology in patients dying of COVID-19: a series of 40 cases including clinical, histologic, and virologic data. Modern Pathology (2020) 33:2147-2155 https://doi.org/10.1038/s41379-020-00649-x

Lei F, Liu YM, Zhou F, Qin JJ, Zhang P, Zhu L, Et al. Longitudinal Association Between Markers of Liver Injury and Mortality in COVID-19 in China. 2020. Hepatology 72 (2). p.389-98.

Lei P, Zhang L, Han P, Zheng C, Tong Q, Shang H, et al. Liver injury in patients with COVID19: Clinical profiles, CT findings, the correlation of the severity with liver injury. 2020. Hepatology International 14:733-742.

Liao FL, Peng DH, Chen W, Hu HN, Tang P, Liu YY, Luo Y, et al. Evaluation of serum hepatic enzyme activities in different COVID-19 phenotypes. 2020. Journal of Medical Virology Wiley. p2365-2373

Mariasih, N. K. 2014. Perbedaan Kadar SGPT/ALT Pecandu Tuak dengan Tidak Pecandu Tuak di Desa Cau Blayu Kabupaten Tabanan. Denpasar: Politeknik Kesehatan Denpasar.

Medetalibeyoglu A, Catma Y, Senkal N, Ormeci A, Cavus B, Kose m, et al. The Effect of liver test abnormalities on the prognosis of COVID-19. Annals of Hepatology 19 (2020) 614-621

Musa S. Hepatic and Gastrointestinal involvement in Coronavirus Disease 2019 (COVID-19): What do we know till now? Arab Journal of Gastroenterology 21 (2020) 3-8.

Nardo A, Gleixner MS, Bakail M, Dixon ED, Lax SF, Trauner M. Pathophysiological mechanism of liver injury in COVID-19. Liver International 2021; 41:20-32

Navarro, V. J. dan Senior, J. R. 2006. Drug-Related Hepatotoxicity. Available at: https://pdfs.semanticscholar.org. Diakses pada tanggal 23 januari 2021.

Perhimpunan Dokter Paru Indonesia, Perhimpunan Dokter Spesialis Kardiovaskular Indonesia, Perhimpunan Dokter Spesialis Penyakit Dalam Indonesia, Perhimpunan Dokter Anestesiologi dan Terapi Intensif Indonesia, Ikatan Dokter Anak Indonesia. Pedoman Tatalaksana COVID-19. Desember 2020

Pratt DS. Liver Chemistry and Function Test. Gastrointestinal and Liver Disease Patophysiology and Liver Disease. 2021. Elsevier: Philadelphia. 1154-63.

Rosida, A. 2016. Pemeriksaan Laboratorium Penyakit Hati. Available at: http://download.portalgaruda.org/article.php Diakses pada tanggal 22 Februari 2018.

Saini RK, Saini N, Ram S, Soni SL, Suri V, Malhotra P, et al. COVID-19 associated variations in liver function parameters: a retrospective study. Postgrad Med J 2020; 0:1-7

Tanoeisan Angelina P. Mewo Yanti M. Kaligis Stefana H.M. 2016, Gambaran kadar serum glutamic pyrupic transaminase (SGPT) pada perokok aktif usia > 40 tahun, Manado: skripsi Fakultas Kedokteran Universitas Sam Ratulangi Manado. 
Thapa, B. R. dan Walia, A. 2006. Liver Function Tests and their Interpretation. Available at: http://medind.nic.in/icb/t07/i7/icbt07i7p663.pdf. Diakses pada tanggal 1 Maret 2018.

Wu H, Liu S, Luo H, Chen M. Progress in the clinical features and pathogenesis of abnormal liver enzymes in Coronavirus Disease 2019. 2021. Journal of Clinical and Translational Hepatology. Vol 9(2). p. 239-46.

Wu J, Song S, Cao HC, Li JL. Liver diseases in COVID-19: Etiology, treatment, and prognosis Yousaf M N, Naqvi H A, Chaudhary F, et al. (November 25, 2020) The Pathophysiology of Gastrointestinal and Hepatic Manifestations of COVID- 19. Cureus 12(11): e11698. DOI 10.7759/cureus.11698

Yang X, Yu Y, Xu J, et al. Clinical course and outcomes of critically ill patients with SARS-CoV2 pneumonia in Wuhan, China: a single-centered, retrospective, observational study. Lancet Respir Med 2020; published online Feb 24. DOI:10.1016/S2213-2600(20)300795.

Yang J, Zheng Y, Gou X, Pu K, Chen Z, Guo Q, Ji R, Wang H, Wang Y, Zhou Y. Prevalence of comorbidities in the novel Wuhan coronavirus (COVID-19) infection: a systemic review and meta-analysis. Int J Infect Dis 2020. doi: 10.1016/j.ijid.2020.03.017.

Zhang C, Shi L, Wang FS. Liver Injury in COVID-19: management and challenges. Lancet Gastroenterohepatology 2020; 5:428-30

Zheng YY, Ma Y'T, Zhang JY, Xie X. Covid-19 and the cardiovascular system. Nat Rev Cardiol 2020. doi: 10.1038/s41569-020-0360-5. 